\author{
Wiesław Alejziak \\ https://orcid.org/0000-0002-0604-7577 \\ Bartosz Szczechowicz \\ https://orcid.org/0000-0002-9019-9396 \\ University of Physical Education in Kraków \\ Faculty of Tourism and Recreation \\ Institute of Entrepreneurship and Management \\ wieslaw.alejziak@awf.krakow.pl, bartosz.szczechowicz@awf.krakow.pl
}

\title{
EXPERT FORECASTS OF THE IMPACTS OF TOURISM TRENDS: ASSESSMENT BY POLISH UNIVERSITY STUDENTS
}

\begin{abstract}
The purpose of the article was to establish whether a tourism student can effectively recognize tourism trends, and to achieve this aim the following research tasks were accomplished: 1) the authors identified 10 trends (and 47 impacts), concerning the transformations that have occurred in tourism in recent years and have been recognized by specialists from the European Travel Commission and the European Tourism Action Group; 2) these trends and their impacts underwent a critical evaluation by students who were given the opportunity to add other impacts (their own) to the specialist list; 3 ) students' evaluations were compared to current trends identified in other academic work. The research was conducted on 95 tourism and recreation students at the University of Physical Education in Kraków and the Vistula School of Hospitality in Warsaw (formerly: Warsaw School of Tourism and Hospitality Management), in 2017/2018 and 2018/2019. The article has also presented the results of earlier research (unpublished) at two other academic centres (Rzeszow and Kielce) on 113 students, 17 lecturers and 76 travel agency employees. Together the results described in this article present the opinions of 301 respondents. It was established that students, as a group, are sufficiently effective observers of changes in the tourism market to make an appropriate contribution and, consequently, are valuable participants at brainstorming sessions. They use what they have learned during their university study, are familiar with forecasting and scenario methods, as well as taking advantage of the imagination and creativity typical of such students.
\end{abstract}

Keywords: tourism, tourism market, trends, foresight, expert method, students.

\section{INTRODUCTION}

In the current situation, the claim arising from much research into tourism that it is an extremely complex phenomenon, is a truism. It is a field where different dimensions or aspects of reality connect and interpenetrate. Due to this complexity, however, tourism is very sensitive to changes in individual tourists' needs and desires, the demographic structure of societies, the availability of natural and cultural resources, technology, the legal environment, etc. As a consequence, it is justifiable, if not necessary, to identify these changes by recognizing various trends (psycho-social, demographic, economic, technological, etc.) in the tourism market. By trends, we mean general regularities (quantitative, qualitative) in shaping given phenomena, regardless of the character of the variables which are being analysed, or the extent of the changes that they undergo. Precisely speaking, we are talking about "short- or long-term phenomena of regional or global range, usually described in economic, sociological and psychological terms (the lifestyles of some market segments and the consumption models related to them), influencing various business sectors" (Vejlgaard, 2008, in Hajdas, SzabelaPasierbińska, 2016, p. 233).

Being aware of current trends is important to many organisations not excepting those operating in the tourism sector. It is, above all, significant for regional or state governments which need a rational basis to create and implement current policies, new laws and assess impacts on the environment, by stimulating trends which are beneficial for society and limiting those which are not, or at least minimizing their negative consequences (Alejziak, Szczechowicz, 2019). This awareness and the resulting knowledge are required by the managers of enterprises and other organizations 
as well so they can make effective decisions regarding their functioning and strategy (e.g. investments). They are also important for individuals who play various social and economic roles so they can make optimal use of their scarce resources (Coathup, 1999; van der Duim, Ren, Jóhannesson, 2013; Inskeep, 1991; Pearce, 2005; Wodejko, 2006; Yiannakis, Gibson, 1992).

Research in order to identify and analyse the trends which influence tourism may involve a variety of methods which serve the purpose of forecasting changes in the macro environment. They may be traditional methods used in forecasting megatrends, microtrends and 'vogues', as well as approaches resembling interdisciplinary studies on the future (Borodako, 2008; Hajdas, Szabela-Pasierbińska, 2016; zob. też EC, 2009)ํ․ Without going into detail, quantitative methods are based on mathematical models in which the values of given variables are extrapolated into the future, while qualitative methods are based on specialist knowledge. Therefore, each group can be matched to a characteristic (desired) profile of the person who is planning and undertaking research on trends.

In the case of quantitative methods, such a person should demonstrate knowledge of academic disciplines as well as analytical skills, while for the qualitative methods, the person should not only be knowledgeable, but also creative, intuitive, experienced, innovative, resourceful and original (Hajdas, Szabela-Pasierbińska, 2016). When it comes to tourism, we must remember that in many situations, a specialist is expected to demonstrate knowledge which is comprehensive, multifaceted and interdisciplinary, and not be selective.

Forecasting is always based on a correct diagnosis of reality (or on the established current state of the phenomena studied), on interdependencies and feedback, as well as the directions and strengths of internal and external factors, existing limitations, etc. When projecting the future, it is possible to use various forecasting techniques which differ, above all, with respect to the time horizon and the number of factors under consideration.

Forecasting offers numerous ways of examining the future and which can be divided into three groups: extrapolative, intuitive and inferential (Grabiński, Wydymus, Zeliaś, 1993; Penc, 1997). The first group includes methods which are based on past development trends, and the basic premises of inference using a range of econometric models. Intuitive methods are not supported with precise calculations, and the whole prognostic process is based on the creative capabilities of the human mind, particularly on associations, free exchange of opinions and submission of ideas. Inferential methods make it possible to predict some phenomena on the basis of others, despite the fact that cause and effect relationships between them have not been found ${ }^{2}$.

In view of the above, the authors assumed that their main aim is to establish whether only an experienced specialist is able to effectively identify current tourism trends, or if this can also be done by a student of tourism. Setting such an aim is based on two assumptions.

Firstly, students are usually young and open-minded, but at the same time they are critical of their surrounding reality which is a good basis for making observations and a sensible assessment of the changes taking place within tourism. At the same time, it makes possible non-standard reasoning which allows the surrounding reality to be looked at in a different way to specialist lines of thought. It is also connected with the fact that current students (the second decade of the $21^{\text {st }}$ century) or recent graduates are representatives of the, so-called, generation ' $Z$ '. Their characteristic traits include self-confidence, openness and acceptance of diversity, awareness of the influence of global problems on the lives of individuals and societies, risk-taking tendencies and the ability to take quick decisions (Chomątowska, Żarczyńska-Dobiesz, 2014). They are also qualities which may make 'today's' students able to effectively identify trends in, for example, tourism.

Secondly, by attending various classes, students acquire up-to-date knowledge in many academic disciplines and this is a good basis for analysing the complexity and multifaceted character of tourism. The multidisciplinary nature of tourism studies is confirmed by an analysis of the graduates' profiles and the syllabuses implemented at different types of universities (regular, economic, technical, humanistic, agricultural, physical education academies, etc. ${ }^{3}$ ), preparing students for work that involves satisfying travellers' needs and wants ${ }^{4}$. It is worth noting that this multidisciplinary character may be an asset for students, in contrast to academic specialists who focus on the detailed examination of a strictly specified fraction of reality ${ }^{5}$.

Let us explain here that university curricula and syllabuses do not always cover the whole of present knowledge and the results of the latest research. This is indicated in analyses by Gołembski who examined the syllabuses of tourism courses at eleven Polish universities with regard to topics corresponding to recent research trends and the most important economic challenges. As a result, he managed to establish those current trends in academia and the economy which are not sufficiently covered at major universities: quality management, the tourist function of urban centres and regions, network approaches in regional studies, innovation, entrepreneurship, and new ideas of regional and enterprise management (Gołembski, 2016).

At this point, it is worth recalling the conclusions drawn from the research among graduates of first degree (BA) Tourism and Recreation studies (2008/2009 and 2009/2010) at the Józef Piłsudski University of Physical Education in Warsaw, Biała Podlaska Branch. It was concluded that tourism students represented a relatively high level of initiative, which could be regarded as above 
average compared to the general population of Polish students. At the same time, the respondents were professionally active (gainful employment, competence development, etc.), though, as the researchers claim, "they were less [...] engaged in the social, organizational or research activity" (Buchta, Skiert, Sikora, 2012, pp. 70-71).

These general indicators regarding tourism students' initiative can be supplemented by employers. In the light of some cross-national empirical studies, conducted among tourism entrepreneurs, tourism graduates demonstrate a satisfactory level of theoretical knowledge, but insufficient experience, assertiveness and innovativeness, to satisfy the entrpreneurs'needs (Szymańska, 2009). The issue of preparing people for work in the tourism sector is not quite clear because the results of other studies show that employers rated the competences of tourism graduates at a relatively low level (Alejziak, 2014).

It should be emphasised, however, that employers probably evaluate graduates' knowledge (and skills) primarily in terms of practical usability, judging how useful they might be in performing specific professional tasks, and not how much the students know about tourism and its trends in general. This is very important from the point of view of this article, as well as natural, considering the fact that at many universities, tourism sub-majors are perceived as practical work (even if they are formally conducted as academic) which is to prepare graduates for work in a wide range of tourism services (cf. Tokarz-Kocik, 2016). On the other hand, however, those representing academic and business environments at the same time remark that "...a situation when a university graduate possesses only practical knowledge and is only a good 'artisan' cannot be allowed" (Głąbiński, 2010).

It is worth mentioning that the students themselves rate their own competences (knowledge) slightly more highly. This does not mean that they are not critical towards themselves or their universities because their self-assessment with regard to many aspects of knowledge and skills is lower than expected (Skiert, Buchta, 2014). To make the picture of tourism graduates complete, we wish to point out that they gain many different skills, including social/soft ones (Łubkowska, Nadobnik, Tarnowski, Nowak, 2017), which, coupled with some hard skills, should define a 'specialist'. The emerging figure of a tourism graduate (regardless of their major) is, it seems, very complex. However, this mainly results from the complexity of tourism, and partly from the fact that the contemporary labour market promotes the, so-called, flexible career model, characterized by an accumulation of knowledge and skills (Bednarska, 2013). All this seems to confirm the wide range of knowledge, as well as other competences, developed by students who complete tourism-related academic courses.

\section{RESEARCH METHODS}

The aim of this article can be expressed in the form of the following research hypothesis: tourism students are able to notice trends in tourism which match specialist indicators. This hypothesis was specified by posing three research questions, referring to tourism students: 1. Does the student have appropriate knowledge and analytical skills which enable him/her to reflect on the complex and multifaceted domain of tourism?

2. Is the student capable of taking a critical attitude to the trends identified by specialists which define changes in tourism?

3. Is the student able to creatively develop the set of trends describing the changes identified by specialists, supplementing it with accurate observations based on his/her own knowledge, personal experience, intuition, etc.?

In order to provide answers to these questions and, consequently, to achieve the research aim, the approach was divided into three stages: (I) identifying the trends regarding the transformations which have taken place in tourism in recent years and confirmed by specialists; (II) students' critical assessment of the trends identified at stage I, combined with the opportunity to complement the specialist list with other trends; (III) comparing students' evaluations on the current trends identified by specialists.

Based on the indicators of the European Travel Commission (ETC - https://stc-corporate.org) and European Tourism Action Group (ETAG - https://www.etag-euro.org) from 2003 and 2006, a list of major trends observed in the socio-economic world was compiled, as well as their impacts and implications for the tourism sector. Altogether, 10 out of the 11 trends described in these reports were selected (one category was omitted from the analysis as is explained later in the text) and 3-7 impacts were ascribed to each of them. A total of ten trends were established, and to each of them was ascribed from three to seven impacts and implications (47). The trends and their impacts are presented in Table 1.

As a research method, the authors chose a diagnostic survey based on a three-part questionnaire. The introductory section explained the aim of the research and included an invitation to take part in the study. The tables contained in the main part provided a description of trends (column 1) and the impacts/implications ascribed to them (column 2). For each impact/implication, an open space was left to mark the probability of its occurrence globally (column 3) and in Poland (column 4). The respondents could indicate probabilities using a Likert scale: 1 - strongly agree, 2 - agree, 3 - undecided, 4 - disagree, 5 - strongly disagree. The table also included three lines for each of the 10 trends where the respondents could add impacts/implications which they believed to be likely in the near future. The 
Table 1. Trends and their impacts/implications for the tourism sector, according to European Travel Commission (ETC) and European Tourism Action Group (ETAG)

\begin{tabular}{|c|c|c|c|}
\hline & Trends & & Impacts/implications (for tourism sector) \\
\hline \multirow{6}{*}{ I } & \multirow{6}{*}{$\begin{array}{l}\text { Demography } \\
\text { The number of elderly } \\
\text { people will grow rapidly. } \\
\text { They will be healthier } \\
\text { and have larger } \\
\text { financial resources at their } \\
\text { disposal. They will decide } \\
\text { to retire earlier. }\end{array}$} & 1 & Increasing demand for quality, comfort, safety \\
\hline & & 2 & Increasing demand for easy and fast transport \\
\hline & & 3 & Increasing demand for more quiet entertainment facilities \\
\hline & & 4 & Increasing demand for products for people travelling alone \\
\hline & & 5 & Larger demand in the months before and after high season \\
\hline & & 6 & In marketing, age will be emphasised less strongly than comfort \\
\hline \multirow{4}{*}{ II } & \multirow{4}{*}{$\begin{array}{l}\text { Health } \\
\text { Health awareness will be } \\
\text { growing. }\end{array}$} & 1 & Travel directions perceived as less healthy will be chosen less often than before \\
\hline & & 2 & The demand for holidays offering only sunbathing will continue to decrease \\
\hline & & 3 & $\begin{array}{l}\text { Active holidays will become increasingly popular, and the demand for facilities } \\
\text { satisfying such needs will be growing }\end{array}$ \\
\hline & & 4 & The demand for bio-regeneration products will be increasing \\
\hline \multirow{3}{*}{ III } & \multirow{3}{*}{$\begin{array}{c}\text { Awareness and education } \\
\text { The average level } \\
\text { of education is rising. }\end{array}$} & 1 & Increasing demand for specialist products \\
\hline & & 2 & Including elements of art, culture and history in organized events and individual holidays \\
\hline & & 3 & A need for better and more creative information transfer \\
\hline \multirow{6}{*}{ IV } & \multirow{6}{*}{$\begin{array}{l}\text { Information technology } \\
\text { The significance } \\
\text { of the internet will continue } \\
\text { to grow (searching } \\
\text { for information, } \\
\text { online shopping). }\end{array}$} & 1 & $\begin{array}{l}\text { Easy access to information about travel directions and tourist products will encourage } \\
\text { people to compare offers and this will influence competition }\end{array}$ \\
\hline & & 2 & $\begin{array}{l}\text { Experienced tourists will more and more often compose their own holidays from } \\
\text { available modules, through direct booking }\end{array}$ \\
\hline & & 3 & $\begin{array}{l}\text { The role of travel agencies will be decreasing, as the online purchase of organized } \\
\text { events is becoming increasingly popular }\end{array}$ \\
\hline & & 4 & $\begin{array}{l}\text { The internet will reduce the role of national tourism organizations and tourism } \\
\text { chambers }\end{array}$ \\
\hline & & 5 & $\begin{array}{l}\text { The accessibility of links to service providers will gain in importance } \\
\text { as a condition for a website to be successful }\end{array}$ \\
\hline & & 6 & $\begin{array}{l}\text { Due to the growing significance of safety, the more critical tourists will feel } \\
\text { a stronger need to make safe online bookings }\end{array}$ \\
\hline \multirow{7}{*}{$\mathrm{V}$} & \multirow{7}{*}{$\begin{array}{l}\text { Transport } \\
\text { Fast trains and cheap airlines } \\
\text { are becoming increasingly } \\
\text { accessible, but on the other } \\
\text { hand, traffic on Polish roads } \\
\text { will be heavier, due to traffic } \\
\text { jams. }\end{array}$} & 1 & Easily accessible and cheap destinations will be chosen more often for short stays \\
\hline & & 2 & Short stays in the countryside will be replaced by stays in large cities \\
\hline & & 3 & Travelling by fast rail will become more popular than scheduled flights \\
\hline & & 4 & Heavy traffic on Polish roads will cause congestion ('traffic jams') \\
\hline & & 5 & Interest in coach tours will be decreasing \\
\hline & & 6 & Interest in sea cruises will increase, especially among tourists over 50 \\
\hline & & 7 & $\begin{array}{l}\text { Difficulty in accessing information about timetables will have a negative effect } \\
\text { on the choice of destination }\end{array}$ \\
\hline \multirow{4}{*}{ VI } & \multirow{4}{*}{$\begin{array}{c}\text { Sustainable development } \\
\text { Environmental awareness } \\
\text { will continue to rise. }\end{array}$} & 1 & Regional destinations will gain in importance \\
\hline & & 2 & $\begin{array}{l}\text { Tourists will be willing to visit places where the locals are happy to receive } \\
\text { growing numbers of tourists }\end{array}$ \\
\hline & & 3 & Tourists will cover some of the costs connected with sustainable development \\
\hline & & 4 & Sustainable tourism is not the same as eco-tourism \\
\hline \multirow{3}{*}{ VII } & \multirow{3}{*}{$\begin{array}{c}\text { Safety } \\
\text { Due to terrorist attacks, } \\
\text { regional wars, crisis situations } \\
\text { and pollution, tourists will } \\
\text { steer away from regions con- } \\
\text { sidered to be dangerous. }\end{array}$} & 1 & $\begin{array}{l}\text { The quality of water in reservoirs and of the drinking water, will determine the } \\
\text { choice of destination }\end{array}$ \\
\hline & & 2 & $\begin{array}{l}\text { Demanding tourists will more frequently complain in situations when products do } \\
\text { not meet the standards of the destination }\end{array}$ \\
\hline & & 3 & The cost of the guarantee of safety will increase \\
\hline \multirow{3}{*}{ VIII } & \multirow{3}{*}{$\begin{array}{l}\text { Free time } \\
\text { The society demand a larger } \\
\text { amount of leisure time and } \\
\text { recreation; hence, the on-tax- } \\
\text { able income will be decreasing. }\end{array}$} & 1 & The need to provide cheap products is increasing \\
\hline & & 2 & The need to offer recreation is increasing \\
\hline & & 3 & One longer holiday is increasingly exchanged for a few shorter holiday breaks \\
\hline
\end{tabular}


Table 1. (cont.)

\begin{tabular}{|c|c|c|c|}
\hline & Trends & & Impacts/implications (for tourism sector) \\
\hline \multirow{6}{*}{ IX } & \multirow{6}{*}{$\begin{array}{c}\text { Experiences } \\
\text { Tourists' expectations } \\
\text { regarding service standard } \\
\text { and the relation between } \\
\text { quality and price } \\
\text { are increasing. Tourists more } \\
\text { often speak openly about } \\
\text { their expectations, growing } \\
\text { needs, which they later } \\
\text { effectively verify. }\end{array}$} & 1 & $\begin{array}{l}\text { There will be stronger competition in tourist services, with respect to the } \\
\text { attractiveness of the program and the destination; alternative ways of spending } \\
\text { money will appear }\end{array}$ \\
\hline & & 2 & $\begin{array}{l}\text { Countries and regions which do not meet the growing expectations and standards } \\
\text { will become less attractive in the long run }\end{array}$ \\
\hline & & 3 & $\begin{array}{l}\text { Clients' behaviours will be diversified (one year travelling abroad, the next - around } \\
\text { the country; one long journey followed with several short ones) }\end{array}$ \\
\hline & & 4 & $\begin{array}{l}\text { Experience and critical approach will encourage tourists to travel to places from } \\
\text { the past ('back to the basics') }\end{array}$ \\
\hline & & 5 & Increased mobility of tourists will have a positive effect on transport rental \\
\hline & & 6 & $\begin{array}{l}\text { Tourists will more and more often choose regions which offer a diversified, full and } \\
\text { completely sustainable conception }\end{array}$ \\
\hline \multirow{5}{*}{$x$} & \multirow{5}{*}{$\begin{array}{l}\text { Lifestyle } \\
\text { For several years we have } \\
\text { been observing changes in } \\
\text { lifestyle, which have } \\
\text { a significant impact } \\
\text { on the way tourists' needs } \\
\text { and behaviours } \\
\text { are perceived. }\end{array}$} & 1 & $\begin{array}{l}\text { Interest in BB ('Bed \& Breakfast') services will decrease, as they are perceived as } \\
\text { low-quality services }\end{array}$ \\
\hline & & 2 & $\begin{array}{l}\text { Changes in lifestyle result in a decreasing interest in purchasing an event in the form } \\
\text { of a ready-made package }\end{array}$ \\
\hline & & 3 & $\begin{array}{l}\text { Tourist vents enriched with new products; services will be purchased more willingly } \\
\text { than those which are currently popular }\end{array}$ \\
\hline & & 4 & $\begin{array}{l}\text { Tourist events combining recreation and an opportunity to enjoy one's hobby will be } \\
\text { purchased more willingly }\end{array}$ \\
\hline & & 5 & $\begin{array}{l}\text { The need to have one's own 'port', stimulating the purchase of a second home, } \\
\text { is becoming increasingly common }\end{array}$ \\
\hline
\end{tabular}

Source: ETC, ETAG (2003); ETC (2006)

final part included a respondent's particulars section where they were asked to disclose their gender and age, as well as contact details.

To accomplish stage II, it was necessary to select a sample from the general population of tourism students. This was a non-probability sample, as the researchers believed that the study should be conducted among students of tourism and recreation. As can be seen from the syllabus, the course is interdisciplinary and this, theoretically, enabled students to evaluate the trends identified by specialists and related to various areas of tourist activity. The study was carried out at two universities: Bronisław Czech University of Physical Education in Kraków (a state university) and the Vistula School of Hospitality in Warsaw (a private educational establishment). Thus, spatially, the research included two of the major Polish academic centres (Kraków and Warsaw), preparing specialists for work on the tourism market, and was conducted in two academic years: 2017/2018 and 2018/2019.

It should be noted at this point that the research which involved students of different universities assessing trends and their impacts indicated in Table 1 , had already started in the academic year of 2007/2008. In subsequent years, however, the study tool (questionnaire) was modified, gradually becoming more respondent-friendly and, above all, more extensive. Initially, the respondents were asked to evaluate the impacts of individual trends identified by specialists, and only in later years could they 'add' impacts which they predicted themselves. This circumstance is one of the reasons why the authors decided to present the results concerning 2017/2018 and 2018/2019. Another justification of this decision is that the trends and their impacts (Table 1) seem still to be true, which derives from the very nature of a trend. As mentioned earlier, trends are largely connected with long-term changes and their development is evolutionary, in contrast to megatrends which mostly cause revolutionary changes (Hajdas, Szabela-Pasierbińska, 2016) ${ }^{6}$.

The study included 101 respondents, mostly MA students and several students of E-tourism, a new course, in the second year of BA studies whose knowledge of information technology was not less than $2^{\text {nd }}$ degree (MA) students. Due to the fact that some participants returned incomplete questionnaires, the final analysis included data from 95 respondents. The characteristics of the study sample are presented in Table 2.

The majority of the 95 respondents were from the University of Physical Education in Kraków, and most of them were female. All the respondents were doing the 'Tourism and Recreation' course, majoring in 'tourism business management', 'SPA centre management', 'outdoor project management', 'motivation and business tourism' (MA studies), or 'e-tourism' (BA studies); at the Vistula School it was 'hospitality' and 
Table 2. Characteristics of the student sample ( $\mathrm{n}=95)$, the university they represent, and gender

\begin{tabular}{|c|c|c|c|c|}
\hline \multirow{2}{*}{ University } & \multicolumn{2}{|c|}{ Gender } & \multirow{2}{*}{ Total } & \multirow{2}{*}{ No data } \\
\hline & Female & Male & & \\
\hline Bronisław Czech University of Physical Educationin Kraków & 45 & 19 & 64 & 0 \\
\hline Vistula School of Hospitality in Warsaw & 15 & 4 & 19 & 12 \\
\hline Total & 60 & 23 & 83 & 12 \\
\hline
\end{tabular}

Source: authors.

'meetings industry management' (MA studies). The respondents were all students, so they were, naturally, of similar age.

\section{RESEARCH RESULTS}

\subsection{STUDENTS' ASSESSMENT OF THE PROBABILITY OF THE IMPACTS OF INDIVIDUAL TRENDS IDENTIFIED BY SPECIALISTS}

As mentioned in the presentation of the research method, the students assessed each trend by subjectively indicating the probability of its impacts/implications predicted earlier by ETC and ETAG specialists. The students used the scale mentioned above. In this way, they not only expressed their subjective opinions, but also critically evaluated specialists' forecasts. By 'critically', we mean both the fact that the students evalu- ated specialist opinions, based on their knowledge and intuition, as well as the fact that they could either agree with those opinions (allocating a score of ' 1 ' or ' 2 ' to them), maintain a neutral attitude (a score of ' 3 '), or have a different opinion (scores of ' 4 ' and ' 5 '). Based on the students' assessments, the authors present the descriptive statistical values in Table 3.

When analysing the data presented in the table, the conclusion that students' assessments were quite similar to specialists' opinions can be arrived at, which may result either from students' trust in the specialists' indicators or from the similarity of opinions. It is confirmed, above all, by the relatively low values of the arithmetical mean. For the whole set of impacts, they fall within the 1.4 to 3.5 range, but if we ignore one more extreme rating of 3.5 (trend $\mathrm{V}$, impact 3 ), the range closes at 2.9, i.e. between 'strongly agree' and 'agree', and possibly 'undecided'. A similar conclusion can be drawn from the analysis of the median and dominant values. In both cases, the median had a value of 1 or 2 , sometimes 3 , and only once of 4 . The dominant also usually

Table 3. Assessment of the probability of a given trend together with its impacts/implications for global tourism $(n=95)$

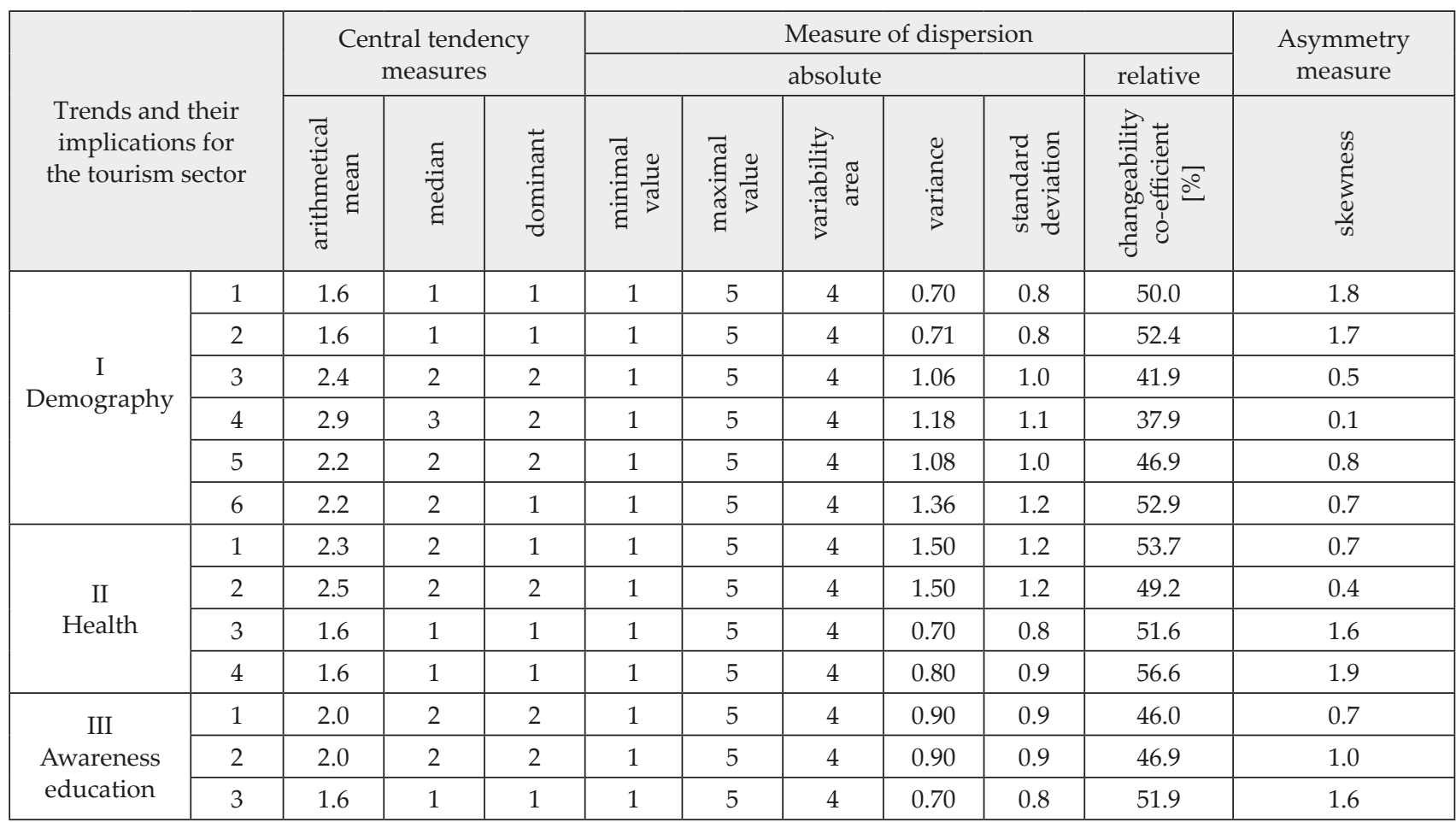


Table 3. (cont.)

\begin{tabular}{|c|c|c|c|c|c|c|c|c|c|c|c|}
\hline \multirow{3}{*}{\multicolumn{2}{|c|}{$\begin{array}{l}\text { Trends and their } \\
\text { implications for } \\
\text { the tourism sector }\end{array}$}} & \multirow{2}{*}{\multicolumn{3}{|c|}{$\begin{array}{c}\text { Central tendency } \\
\text { measures }\end{array}$}} & \multicolumn{6}{|c|}{ Measure of dispersion } & \multirow{3}{*}{ 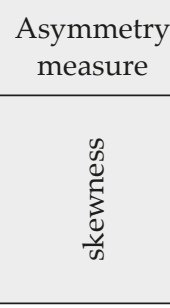 } \\
\hline & & & & & \multirow{3}{*}{ 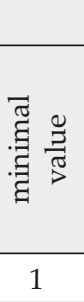 } & \multicolumn{3}{|c|}{ absolute } & \multirow{3}{*}{ 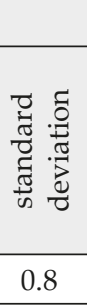 } & \multirow{3}{*}{ 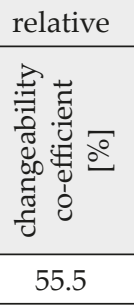 } & \\
\hline & & \multirow{2}{*}{ 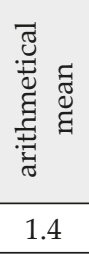 } & \multirow{2}{*}{ 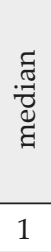 } & \multirow{2}{*}{ 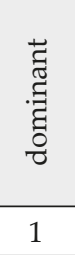 } & & . & : & 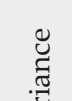 & & & \\
\hline \multirow{6}{*}{$\begin{array}{c}\text { IV } \\
\text { Information } \\
\text { technologies }\end{array}$} & 1 & & & & & 5 & 4 & 0.60 & & & 2.4 \\
\hline & 2 & 1.6 & 1 & 1 & 1 & 5 & 4 & 0.70 & 0.8 & 52.0 & 1.7 \\
\hline & 3 & 2.0 & 2 & 1 & 1 & 5 & 4 & 1.30 & 1.1 & 57.4 & 0.9 \\
\hline & 4 & 2.5 & 2 & 3 & 1 & 5 & 4 & 1.30 & 1.1 & 45.9 & 0.3 \\
\hline & 5 & 1.9 & 2 & 2 & 1 & 5 & 4 & 0.80 & 0.9 & 43.3 & 0.7 \\
\hline & 6 & 2.0 & 2 & 2 & 1 & 5 & 4 & 1.00 & 1.0 & 49.2 & 0.9 \\
\hline \multirow{7}{*}{$\begin{array}{c}\text { V } \\
\text { Transport }\end{array}$} & 1 & 2.3 & 2 & 2 & 1 & 4 & 3 & 1.20 & 1.1 & 48.8 & 0.4 \\
\hline & 2 & 2.9 & 3 & 3 & 1 & 5 & 4 & 1.10 & 1.0 & 35.1 & -0.1 \\
\hline & 3 & 3.5 & 4 & 4 & 1 & 5 & 4 & 1.00 & 1.0 & 28.4 & -0.6 \\
\hline & 4 & 2.0 & 2 & 3 & 1 & 5 & 4 & 1.20 & 1.1 & 54.8 & 0.9 \\
\hline & 5 & 2.2 & 2 & 3 & 1 & 4 & 3 & 1.10 & 1.0 & 46.2 & 0.5 \\
\hline & 6 & 2.2 & 2 & 3 & 1 & 4 & 3 & 0.80 & 0.9 & 41.0 & 0.5 \\
\hline & 7 & 2.2 & 2 & 3 & 1 & 5 & 4 & 0.90 & 1.1 & 49.7 & 0.9 \\
\hline \multirow{4}{*}{$\begin{array}{c}\text { VI } \\
\text { Sustainable } \\
\text { development }\end{array}$} & 1 & 2.4 & 2 & 2 & 1 & 4 & 3 & 0.70 & 0.8 & 34.9 & 0.0 \\
\hline & 2 & 2.5 & 2 & 2 & 1 & 5 & 4 & 1.20 & 1.1 & 43.8 & 0.6 \\
\hline & 3 & 2.6 & 3 & 2 & 1 & 5 & 4 & 0.90 & 0.9 & 35.3 & 0.4 \\
\hline & 4 & 2.4 & 2 & 2 & 1 & 4 & 3 & 0.90 & 0.9 & 39.4 & 0.2 \\
\hline \multirow{3}{*}{$\begin{array}{l}\text { VII } \\
\text { Safety }\end{array}$} & 1 & 2.5 & 3 & 1 i 3 & 1 & 5 & 4 & 1.30 & 1.1 & 46.2 & 0.1 \\
\hline & 2 & 1.9 & 2 & 2 & 1 & 5 & 4 & 0.90 & 0.9 & 49.2 & 1.2 \\
\hline & 3 & 1.8 & 2 & 2 & 1 & 5 & 4 & 0.70 & 0.8 & 45.6 & 1.5 \\
\hline \multirow{3}{*}{$\begin{array}{c}\text { VIII } \\
\text { Leisure time }\end{array}$} & 1 & 2.4 & 2 & 2 & 1 & 5 & 4 & 1.30 & 1.1 & 48.3 & 0.4 \\
\hline & 2 & 1.8 & 2 & 2 & 1 & 5 & 4 & 0.90 & 0.9 & 50.4 & 1.3 \\
\hline & 3 & 2.3 & 2 & 1 & 1 & 5 & 4 & 1.30 & 1.2 & 51.1 & 0.6 \\
\hline \multirow{6}{*}{$\begin{array}{c}\text { IX } \\
\text { Experiences }\end{array}$} & 1 & 1.5 & 1 & 1 & 1 & 5 & 4 & 0.50 & 0.7 & 46.8 & 1.7 \\
\hline & 2 & 2.2 & 2 & 2 & 1 & 5 & 4 & 1.10 & 1.0 & 46.8 & 0.7 \\
\hline & 3 & 2.3 & 2 & 2 & 1 & 5 & 4 & 1.00 & 1.0 & 42.9 & 0.5 \\
\hline & 4 & 2.7 & 3 & 2 & 1 & 4 & 3 & 0.90 & 1.0 & 35.1 & 0.0 \\
\hline & 5 & 2.0 & 2 & 2 & 1 & 4 & 3 & 0.60 & 0.8 & 38.4 & 0.7 \\
\hline & 6 & 1.8 & 2 & 2 & 1 & 4 & 3 & 0.50 & 0.7 & 39.3 & 0.9 \\
\hline \multirow{5}{*}{$\begin{array}{c}X \\
\text { Life style }\end{array}$} & 1 & 2.8 & 3 & 4 & 1 & 5 & 4 & 1.40 & 1.2 & 42.5 & 0.0 \\
\hline & 2 & 2.7 & 3 & 2 & 1 & 5 & 4 & 1.20 & 1.1 & 40.2 & 0.0 \\
\hline & 3 & 1.9 & 2 & 2 & 1 & 5 & 4 & 0.90 & 0.9 & 48.8 & 1.1 \\
\hline & 4 & 1.5 & 1 & 1 & 1 & 5 & 4 & 0.40 & 0.7 & 44.0 & 1.9 \\
\hline & 5 & 2.2 & 2 & 2 & 1 & 5 & 4 & 0.90 & 1.0 & 44.0 & 0.4 \\
\hline
\end{tabular}

Source: authors.

had values of 1 and 2, in several cases of 3 , and in two cases of 4 .

In view of this, it is worth considering the students' inclination to allocate a score of ' 3 '. Such scores, which express 'lack of opinion' about a given issue, can be regarded as 'safe' and imply that the respondents have not formed an opinion on the probability of a given impact due to insufficient knowledge or other reasons. Let us note that in the whole group of respondents, the total number of ' $3 s^{\prime}$ given to all 47 impacts was 691, 
while, theoretically, they could have been allocated 4465 times, provided all the respondents $(n=95)$ had assessed each of the 47 impacts at ' 3 '. In other words, students' tendency to score neutral is $15.5 \%$ and, in consequence, the tendency to assume an attitude (positive or negative) equals $84.5 \%$. The value of this last indicator seems relatively high, which points to the respondents' confidence when expressing opinions. Let us add that among the respondents who chose a score different than ' 3 ', an opinion agreeing with the specialists' indicators (scores ' 1 ' and ' 2 '), was expressed by $82.4 \%$ and a different opinion (' 4 ' and ' 5 ') by $17.6 \%$.

The overview of the results presented above does not mean, however, that the respondents unequivocally shared ETC and ETAG specialists' opinions on ongoing or anticipated changes in the tourism sector. With reference to each impact, the minimal value is 1 and the maximal is 5 , nearly every time. Thus, the variance range of scores is very wide, or in fact maximum. This, in conjunction with a standard deviation ranging from 0.7 and 1.2 , as well as a variance rate, ranging from $35 \%$ to $55 \%$, points to a substantial dispersion of the students' scores around mean values. Let us add, however, that in the majority of cases, the distribution of scores is skewed right and asymmetrical (sometimes the skewness is very strong), so they tilt towards 'low' scores.

When analysing the preliminarily results, let us look more closely at the impacts which the students tended to assess differently to the ETC and ETAG specialists, particularly 'travelling by fast rail will become more popular than scheduled flights'. It is worth emphasising that the specialists' opinions which the study refers to were formulated in 2003 and 2006 based on data available in the early years of the $21^{\text {st }}$ century. The respondents, however, gave their scores several years later, based on their knowledge of the current development of certain phenomena which could only have been predicted by the specialists. Therefore, students' observations regarding, for instance, tourists' demand for different types of transport services, can be assessed positively as a result of an independent, critical look at the formulated thesis.

The data collected in the course of the study underwent analysis in order to discover possible differences in the respondents' opinions, depending on gender. For this purpose, a compilation of basic descriptive statistics was prepared, analogous to the contents of Table 3, but separately for men and women. However, preliminary analysis of values did not clearly demonstrate any influence of gender on the scores allocated to individual trends or impacts. As regards these trends, some impacts had slightly higher scores for women, and others for men. It is interesting, however, that women were more decisive in their opinions, i.e. they relatively rarely gave a ' 3 ' to the impacts. For women, ' $3 s^{\prime}$ appeared in $12.2 \%$ of possible cases, while for men, it was $15.4 \%$.
In the description of the questionnaire, it was noted that the respondents allocated each impact the probability of its occurrence globally (discussed above) and on a national scale with reference to the tourism sector in Poland. Without going into much detail regarding the comparison of these two sets, let us just say, referring to the basic measure of central tendency, that for only seven out of the 47 evaluated impacts, did indicators on a global scale demonstrate a higher value of arithmetical mean. In one case, they were equal (rounded to one decimal place), and in 39 cases Poland achieved higher scores. Thus, it seems that students tend to ascribe a slightly higher probability of occurrence to global than national impacts. It should be added here that differences between mean values were relatively small.

Considering the possible criteria diversifying students' answers, it is worth referring to the results of pilot studies which were conducted in the academic years 2014/2015 and 2015/2016 among BA students ( $3^{\text {rd }}$ year) and MA students (2nd year) of Economics at the Professor Edward Lipinski School of Economics, Law and Medical Sciences in Kielce, specializing in Managerial Economics. They were 'non-tourist' $2^{\text {nd }}$ degree courses, but the students also took some subjects related to tourism, or strictly 'tourist' (a monographic lecture or 'Tourism Economics' classes). The research used a slightly different questionnaire (some of the trends were described through other impacts; it was not possible to add personal ideas). The results show that arithmetical mean values fall within a similar range to tourism and recreation students: $1.3-3.3$. At the same time, for a larger number of impacts, the arithmetical mean was estimated at 3.0 or higher. The results of both studies also turned out to be similar as regards median and dominant values (the students from Kielce usually had scores of 1 or 2), but significantly different as regards the tendency to give neutral scores, i.e. ' 3 ' (undecided). Let us remember that among the students from Kraków and Warsaw, this tendency was rated at $13.5 \%$, and among the students from Kielce at $6.4 \%$, which means that the students of economics were more decisive in their opinions.

\subsection{AN EXTENDED SET OF THE IMPACTS OF INDIVIDUAL TRENDS INDICATED BY SPECIALISTS}

Analysis of the research results so far suggests that the respondents tended to agree with specialists' forecasts concerning transformations in the tourism sector. Such advanced congruity of students' and specialists' opinions is not, however, an expression of a passive attitude of the former and their inability to hold a position of their own, or of their lack of criticism. It turned out that the respondents expressed their critical 
attitude towards the set of impacts presented to them by complementing it with their own indicators of changes which they anticipated in the tourism sector. There were a relatively large number of such original ideas, 474 , added to the questionnaire. Let us note, however, that not every respondent wrote down the impacts they predicted; only from 63 respondents, some of whom referred to nearly every trend. The number of 'original' implications anticipated by the students is included in Table 4, with respect to respondents' gender.

When analysing the data given above, it can be noticed that the number of students' 'original' ideas varies: the fewest were ascribed to the 'experiences' trend (29), and the largest number to 'demography' (76). Explanation of this goes beyond the scope of this text, though it may imply that there are areas in which students feel more confident, have better knowledge/intuition and are willing to share. There are also areas where they feel less confident and less willing to express opinions. It is noteworthy, however, that a great majority of those who wrote anything $(48-76.3 \%)$ were female. In view of this, let us note that with respect to eight trends, women entered more comments than could be expected from their percentage in the total number of respondents who indicated impacts other than those anticipated by the WTC and ETAG specialists. Women dramatically outnumbered men when it came to writing extra comments on the 'lifestyle' trend, as many as 35 out of 40 were provided by women. This seems a good foundation for two hypotheses whose verification would require further research. According to the first one, female students show a stronger tendency to share opinions on ongoing or anticipated changes in the tourism sector than male; according to the other, the tendency to present these opinions varies depending on the domain concerned.
Without recalling all the impacts indicated by the study participants (474), let us focus only on those for two selected trends referred to as 'information technologies' and 'experiences'. The choice of these trends is arbitrary, but it was prompted by the wish to compare trends in areas of reality which significantly differ from each other. In this regard, 'information technologies' represents contemporary, modern, science phenomena and as such, they may be closer to students as young people (Generation Z). On the other hand, 'experiences' refers to the timeless, humanistic outlook on reality, as well as people's needs and desires.

The two tables below present the impacts of the two trends indicated by the students. For clarity, these impacts were divided into groups and their characteristic subsets were described by means of generalizations. It must be said, however, that it was not the only way to group them because some of the impacts refer to different aspects of a given trend. Let us add that the tables do not contain data on the probability of occurrence of individual implications because those added were usually indicated by single students and their occurrence was regarded as highly probable (1- 'strongly agree' or 2 - 'agree'). Table 5, compiled in this way, presents the impacts of the 'information technologies' trend.

When analysing the contents of this table, it should be noted that students considerably extended the set of impacts which they had been given for assessment. They added 60 indicators which undoubtedly refer to several significant phenomena related to IT development. They pointed to some fundamental issues by expressing their opinions about the role of traditional and modern travel agencies, as well as questioning the influence of those technologies on interest in travel (in the traditional sense of the word), and the predominant form of trips

Table 4. The number of original impacts/implications for the tourism sector, ascribed to individual trends, by gender

\begin{tabular}{|c|c|c|c|c|c|c|}
\hline & & & Nun & ed impac & tions & \\
\hline & rends in the tourism sector & Totol & & & & \\
\hline & & 10 tal & & & & \\
\hline $\mathrm{I}$ & Demography & 76 & 52 & $68.4 \%$ & 24 & $31.6 \%$ \\
\hline II & Health & 51 & 41 & $80.4 \%$ & 10 & $19.6 \%$ \\
\hline III & Awareness and education & 50 & 40 & $80.0 \%$ & 10 & $20.0 \%$ \\
\hline IV & Information technologies & 60 & 46 & $76.7 \%$ & 14 & $23.3 \%$ \\
\hline $\mathrm{V}$ & Transport & 37 & 29 & $78.4 \%$ & 8 & $21.6 \%$ \\
\hline VI & Sustainable development & 36 & 30 & $83.3 \%$ & 6 & $16.7 \%$ \\
\hline VII & Safety & 51 & 40 & $78.4 \%$ & 11 & $21.6 \%$ \\
\hline VIII & Leisure time & 39 & 29 & $74.4 \%$ & 10 & $15.6 \%$ \\
\hline IX & Experiences & 29 & 23 & $79.3 \%$ & 6 & $20.7 \%$ \\
\hline$x$ & Lifestyle & 45 & 40 & $88.9 \%$ & 5 & $11.1 \%$ \\
\hline Total & & 474 & 370 & - & 104 & - \\
\hline
\end{tabular}

Source: authors. 
Table 5. Impacts/implications of trend 4, indicated individually by students 'information technologies'

\begin{tabular}{|c|c|c|c|}
\hline No & No of resp. & Impacts/implications for the tourism sector & Category \\
\hline 1 & 70 & $\begin{array}{l}\text { Travel agencies will still be very important, due to many people's unwillingness to make } \\
\text { online purchases }\end{array}$ & \multirow{5}{*}{$\begin{array}{c}\text { Traditional } \\
\text { travel } \\
\text { agencies }\end{array}$} \\
\hline 2 & 4 & $\begin{array}{l}\text { There will still be many people preferring personal contact with a travel agency employee; } \\
\text { coffee, tea, etc. }\end{array}$ & \\
\hline 3 & 82 & Travel agencies: raising the standard, direct sale & \\
\hline 4 & 76 & $\begin{array}{l}\text { Increasing number of online ticket bookings and purchases leads to a decrease in employment } \\
\text { (tourist office, checkout desks) }\end{array}$ & \\
\hline 5 & 56 & The importance of online consultants, advisors will increase & \\
\hline 6 & 55 & Easy communication /contact with the travel agency / holiday destination & \multirow{7}{*}{$\begin{array}{c}\text { Access } \\
\text { to informa- } \\
\text { tion }\end{array}$} \\
\hline 7 & 76 & Clients' growing awareness due to easy access to information & \\
\hline 8 & 98 & $\begin{array}{l}\text { The most important thing on the internet is the access to offers at one place and the opportunity } \\
\text { to compare them, as well as the ease of organizing a trip without leaving home }\end{array}$ & \\
\hline 9 & 53 & $\begin{array}{l}\text { The number of specialized portals comparing offers and enabling people to make reservations } \\
\text { and purchases will increase }\end{array}$ & \\
\hline 10 & 72 & Growing significance of information websites and local ratings (e.g. TripAdvisor) & \\
\hline 11 & 57 & Applications presenting and comparing offers & \\
\hline 12 & 55 & Access to information regarding safety at the holiday destination & \\
\hline 13 & 52 & Increasing influence of the social media on tourism & \multirow{4}{*}{ Social media } \\
\hline 14 & 91 & $\begin{array}{l}\text { Increased influence of social media on the recognizability of and demand for travel agencies, } \\
\text { sites, etc. }\end{array}$ & \\
\hline 15 & 85 & Increasing importance of the opinions posted on the internet & \\
\hline 16 & 54 & Looking for information provided by other tourists and individual offers & \\
\hline 17 & 66 & More demanding clients & \multirow{5}{*}{$\begin{array}{c}\text { Independent } \\
\text { organization } \\
\text { of travel }\end{array}$} \\
\hline 18 & 51 & Better matching of trips to individual needs & \\
\hline 19 & 89 & $\begin{array}{l}\text { Growing demand for travelling on your own (based on vast knowledge about a given place, } \\
\text { gained from the internet) }\end{array}$ & \\
\hline 20 & 62 & Demand for organizing travel independently & \\
\hline 21 & 5 & In my opinion, Poles prefer to buy complete packages - organized events & \\
\hline 22 & 92 & Development of mobile applications & \multirow{13}{*}{$\begin{array}{l}\text { Mobile } \\
\text { applications }\end{array}$} \\
\hline 23 & 53 & Growing number of mobile applications facilitating travel & \\
\hline 24 & 72 & Growing significance/role of applications in the tourism sector & \\
\hline 25 & 90 & Larger demand for tourism applications & \\
\hline 26 & 58 & Development of tourism applications will cause a decrease in couriers' and guides' services & \\
\hline 27 & 64 & $\begin{array}{l}\text { Decreasing interest in human guides and growing interest in guide applications + e.g. Google } \\
\text { with object recognition function + information about it }\end{array}$ & \\
\hline 28 & 67 & The demand for guide applications will increase & \\
\hline 29 & 77 & Increasing demand for mobile booking or guiding applications & \\
\hline 30 & 61 & Increased comfort when booking a trip & \\
\hline 31 & 89 & Opprtunity to make purchases or bookings over mobile phones & \\
\hline 32 & 67 & Demand for recreation applications will increase & \\
\hline 33 & 72 & $\begin{array}{l}\text { Growing demand for interactive visits to exhibitions, decreasing interest in visiting 'boring' } \\
\text { museums }\end{array}$ & \\
\hline 34 & 78 & $\begin{array}{l}\text { There will be no need to use guides and couriers as you can find everything on your } \\
\text { smartphone }\end{array}$ & \\
\hline 35 & 60 & $\begin{array}{l}\text { Access to the internet is increasingly determining the choice of the destination and, later, } \\
\text { satisfaction }\end{array}$ & \multirow{5}{*}{$\begin{array}{l}\text { Modern } \\
\text { technologies } \\
\text { at the holiday } \\
\text { destination }\end{array}$} \\
\hline 36 & 8 & Increasing demand for the digitalization of the visited places, i.e. on-site internet & \\
\hline 37 & 83 & Smaller demand for room equipment (TV); wi-fi is more important & \\
\hline 38 & 100 & $\begin{array}{l}\text { The choice of accommodation offering a wide range of possibilities to use modern information } \\
\text { technologies will increase }\end{array}$ & \\
\hline 39 & 90 & Growing significance of technology at hotels, tourist sites, information points & \\
\hline
\end{tabular}


Table 5. (cont.)

\begin{tabular}{|c|c|c|c|}
\hline No & No of resp. & Impacts/implications for the tourism sector & Category \\
\hline 40 & 63 & Offers are directed mainly to young people & \multirow{3}{*}{$\begin{array}{l}\text { Specific } \\
\text { segments } \\
\text { of clients }\end{array}$} \\
\hline 41 & 94 & $\begin{array}{l}\text { Many elderly people are afraid of trips which are not organized by specialists (language } \\
\text { barrier, technological barrier - inability to use equipment) }\end{array}$ & \\
\hline 42 & 58 & $\begin{array}{l}\text { Development of applications enables the disabled or blind people to break the barriers } \\
\text { while sightseeing }\end{array}$ & \\
\hline 43 & 51 & Decreasing general integration during trips & \multirow{2}{*}{$\begin{array}{c}\text { Social } \\
\text { contacts while } \\
\text { travelling } \\
\end{array}$} \\
\hline 44 & 51 & Increasing integration among people sharing the same interests & \\
\hline 45 & 64 & Fewer people will leave home, using the possibility of virtual travel & \multirow{4}{*}{$\begin{array}{l}\text { Interest } \\
\text { in going } \\
\text { on a trip }\end{array}$} \\
\hline 46 & 65 & The number of trips may decrease as it is possible to see the same on the Internet & \\
\hline 47 & 63 & Social laziness & \\
\hline 48 & 45 & People will spend more time at home, because there will be more distance working & \\
\hline 49 & 58 & The role of travel agencies will be limited to organizing incentive travel & \multirow{12}{*}{ Other } \\
\hline 50 & 52 & Hotel chains will be superseded by the sharing economy & \\
\hline 51 & 62 & Demand for slow life among tourists & \\
\hline 52 & 71 & Enterprises which don't have a website will practically disappear & \\
\hline 53 & 66 & Fighting for a client (lowering prices, raising standards) & \\
\hline 54 & 95 & Trust in online travel agencies will increase & \\
\hline 55 & 61 & Growing marketing of tourism organizers & \\
\hline 56 & 77 & Demand for advertising on the Internet or through services like Google & \\
\hline 57 & 78 & $\begin{array}{l}\text { A larger number of bookings because the client can buy without much reflection on wheth- } \\
\text { er they can afford it - impulsive sale }\end{array}$ & \\
\hline 58 & 85 & Internet must reduce the cognitive urge to see something 'live', not only on a photo & \\
\hline 59 & 63 & A growing number of jobs for computer specialists, programmers & \\
\hline 60 & 90 & More active hackers, viruses, endangered money transfers & \\
\hline
\end{tabular}

Source: autors.

made by contemporary tourists. They also expressed their opinions on changes regarding access to information, taking into account the problem of communication between consumer communities, e.g. through social media. They also commented on the significance of mobile applications for satisfying the needs of today's tourists, as well as the amenities expected at holiday destinations. Students as a group also referred to modern phenomena such as the sharing economy or a slow life. When reading these quite optimistic results, let us remember, however, that the additional questionnaire entries discussed here were made by individuals, so they express the activeness and perceptiveness of individual students, and not the whole community.

In the same way, Table 6 presents the impacts of the 'Experiences' trend where students made the smallest number of additional entries.

In this case, the students' indicators, grouped into five categories, are visibly less numerous and less diversified. What is important, considering the way some entries were formulated, is that it seems doubtful if they can be qualified as 'experiences'. Even if the entries grouped

Table 6. Impacts/implications of trend 9, indicated individually by students 'experiences'

\begin{tabular}{|c|c|l|c|}
\hline No & No of resps & \multicolumn{1}{|c|}{ Significance/implications for the tourism section } & Category \\
\hline 1 & 83 & Need for extreme adventure travel & \\
\hline 2 & 85 & Demand for extreme experiences & \multirow{2}{*}{$\begin{array}{c}\text { Character } \\
\text { of experiences }\end{array}$} \\
\hline 3 & 90 & Increasing demand for exotic, surprising, modern places & \\
\hline 4 & 91 & Stronger desire to discover new, unknown places & \\
\hline 5 & 72 & Market overload with perfection, high standard and need for 'authenticity' & \\
\hline 7 & 72 & Growing importance of small homesteads/guesthouses & \\
\hline
\end{tabular}


Table 6. (cont.)

\begin{tabular}{|c|c|c|c|}
\hline No & No of resps & Significance/implications for the tourism section & Category \\
\hline 8 & 77 & Raising the standard of services & \multirow{9}{*}{$\begin{array}{c}\text { Quality } \\
\text { and innovativeness } \\
\text { of services }\end{array}$} \\
\hline 9 & 78 & Higher quality of services & \\
\hline 10 & 1 & Growing expectations regarding accommodation, transport & \\
\hline 11 & 95 & Larger comfort of transport and stay & \\
\hline 12 & 95 & Better quality of service, meals, etc. & \\
\hline 13 & 63 & Raising the standard of hotel/carriers' services & \\
\hline 14 & 58 & Increasing demand for luxury goods & \\
\hline 15 & 65 & Larger demand for innovative attractions & \\
\hline 16 & 11 & $\begin{array}{l}\text { Tourists are increasingly choosing regions with unique, modern glass bridges } \\
\text { over a precipice; something giving a boost of adrenaline }+ \text { an exotic location }\end{array}$ & \\
\hline 17 & 82 & Stronger need for exotic, independent trips & \multirow{3}{*}{$\begin{array}{c}\text { Travel } \\
\text { organization model }\end{array}$} \\
\hline 18 & 58 & Tourists will organize cheap holidays by themselves less frequently & \\
\hline 19 & 58 & Tramping will become less important & \\
\hline 20 & 5 & People are becoming aware of their rights and complain more often & \multirow{5}{*}{$\begin{array}{l}\text { Complaints } \\
\text { and company } \\
\text { activity }\end{array}$} \\
\hline 21 & 71 & The number of complaints at tourist agencies will increase & \\
\hline 22 & 61 & $\begin{array}{l}\text { Growing interest in complaining about an event which did not meet the } \\
\text { client's expectations }\end{array}$ & \\
\hline 23 & 77 & More frequent attempts of insurance fraud & \\
\hline 24 & 61 & Small tourist enterprises going bankrupt & \\
\hline 25 & 66 & Scrupulous, meticulous search for offers and verifying programs & \multirow{5}{*}{ Other } \\
\hline 26 & 66 & Returning to a given place after being satisfied with the program & \\
\hline 27 & 67 & Many travel options, e.g. by plane, by car, etc. & \\
\hline 28 & 67 & Competition among carriers & \\
\hline 29 & 85 & Competition will be followed by a decrease in the prices of tourist services & \\
\hline
\end{tabular}

Source: authors.

into categories: 'Character of experience', 'Quality and innovativeness of services' and 'Travel organization model' fit into the wide-ranging domain of tourist experiences, the entries in the two remaining categories, i.e. 'Complaints and company activities' and 'Other' can hardly be interpreted as travellers' experiences and emotions. It can be assumed that students' ability to observe, notice and articulate the transformations in the tourism sector depends on the domain which a transformation concerns. A similar conclusion can be reached if we look at the students' entries regarding the remaining nine trends, but discussing them would go beyond the scope of this research.

\subsection{COMPARING THE IMPACTS OF INDIVIDUAL TRENDS INDICATED BY STUDENTS WITH THE OPINIONS OF RESEARCHERS AND TRAVEL AGENTS}

The research presented in the previous chapter was carried out in 2017-2019. It was, however, a continuation of a project conducted from 2010 which, despite a slightly different character and aims, largely corresponded to the issues presented above. It seems that those earlier studies fitted into the aims described in this article, therefore they will be presented below and used to provide answers to the research questions posed in this work.

The research was conducted in 2010-2012 among the employees and students of the University of Information Technology and Management in Rzeszów (at that time employing one of the authors of this article) as well as among employees of travel agencies in this city. The study was undertaken within the experimental framework of the 'Tourism policy' course (on the last year of MA studies, Tourism and Recreation major), during classes on the influence of megatrends on the functioning of the tourism market. The study was connected with work on a new method, currently referred to by different authors as the Sequential Analysis of Tourist Trends (Alejziak, 2012), which was being developed and 'tested' at that time during classes with students. Both, the method itself and the results were later used in the MA theses of three students who had access to the results (see Gałek, 2011; Kusiak, 2011; Pichura, 2011).

This study (from 2011) included three groups of respondents. The first one consisted of employees of the Faculty of Tourism Economy (FTE) at the University of 


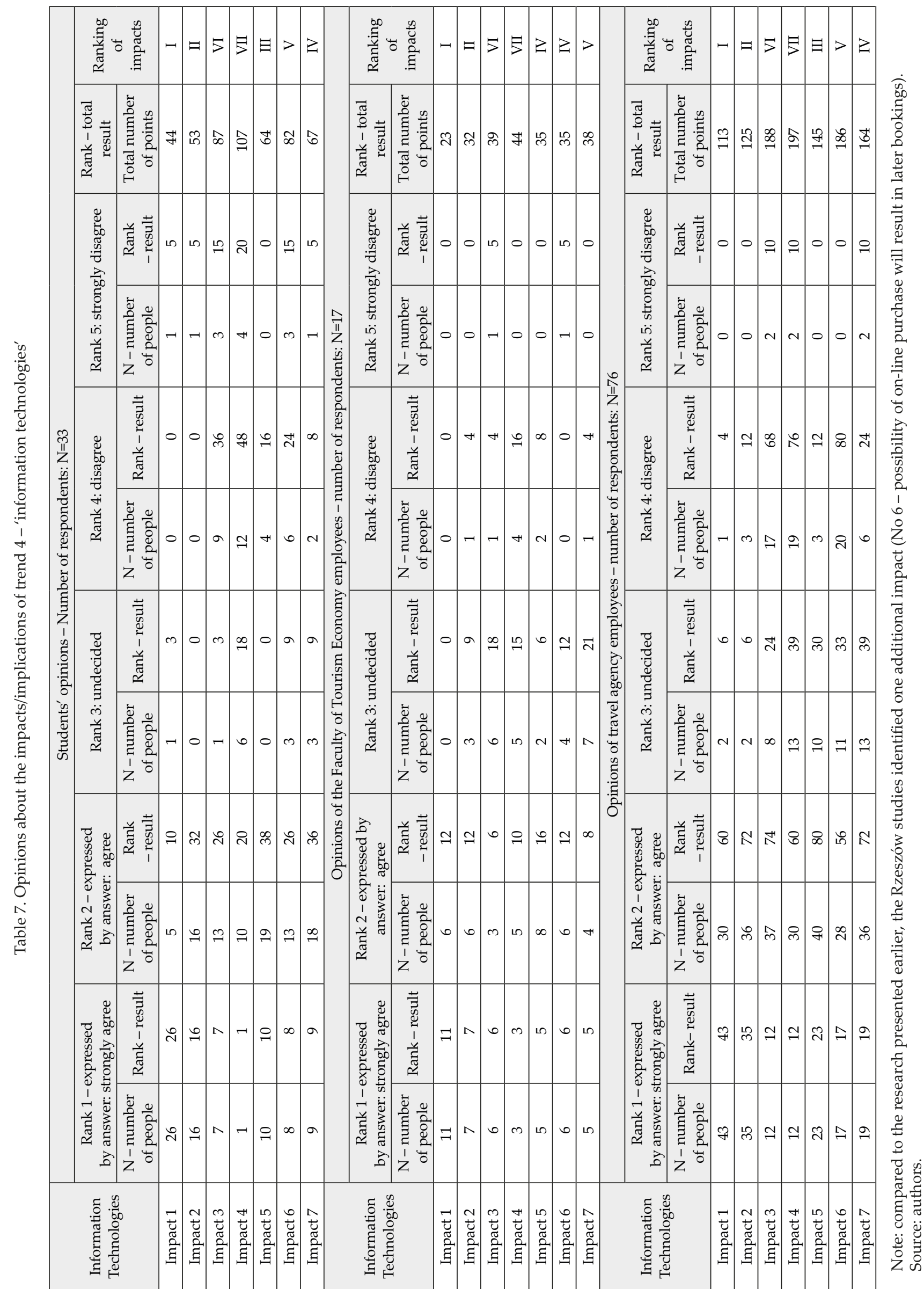


Information Technology and Management in Rzeszów who delivered 17 correctly filled-in paper questionnaires. The second research group was of $352^{\text {nd }}$ year MA students of tourism and recreation $(S)$ who provided detailed answers in 33 questionnaires (the remaining two were incomplete and were excluded). The last and the largest group were employees of Rzeszów travel agencies (TA) who filled in the questionnaire available on www.webankieta.pl. In total, 93 questionnaires were collected, 76 of which qualified for further analysis ( 17 were rejected due to a lack of some answers).

For the purpose of analysis, each variable and answer provided by the respondents was ascribed a rank, based on the assumption that the lower the value of the total result (rank-sum), the higher the probability that a given impact will occur as a consequence of the trend in question. Then again, the higher the value of the total result, the lower this probability. The aim was to create a ranking of the probability of occurrence of individual impacts, and indirectly to define the influence of individual trends in the tourism market. The result may be defined by ordering the impacts from ' 1 ' to ' $n$ ', where ' $n$ ' signifies the number of analysed impacts, and matching the order from ' 1 ' to ' $n x^{\prime}$, where ' $n x$ ' signifies the order of probability according to the adopted assumptions. As a result, the impact with the lowest value of the total result was the most probable and marked as ' $\mathrm{I}$ ', and the impact with the highest value was least probable. The results of these analyses with reference to the two trends, 'information technologies' and 'experiences', are given below.

Table 7 presents the opinions of students, lecturers at the Faculty of Tourism Economy and employees of Rzeszow travel agencies. ETC and ETAG specialists' opinions most strongly agreed with respondents' opinions as regarding no 1, assuming that increasingly easy access to tourist information will allow tourists to obtain more data about a destination, as well as compare prices, and in this way will have a growing influence on competition. On the other hand, the respondents believed that the least probable impact was no 4: 'the internet will have a rapidly decreasing role in Polish tourism organizations'. All the answers are presented on the table. It is worth noting that that students' opinions demonstrated a greater similarity to those presented by the lecturers as regards the more probable impacts, and in the case of the less probable ones, the students' opinions were more similar to the statements of travel agency employees.

Interesting conclusions can be drawn from the comparison of the mean values of indicators on the probability of individual impacts which can be calculated by dividing the total value of all indicators in individual groups by their frequency. Here are the figures for impact 1: students - 1.333 (44:33); lecturers - 1.353 (23:17); travel agency employees - 1.487 (113:76). Thus, the figures are quite similar in all the groups. In the case of impact 4: students - 3.242 (107:33); lecturers - 2.588 (44:17), travel agency employees - 2.592 (197:76).

The analysis of the results, which involved defining the rank (order) of the probability of the analysed impacts (Table 8), reveals that all groups of respondents indicated exactly the same impacts which, they believed, were most (impact 1 ) and least (impact 7) probable. It is worth noting that students' and travel agency employees' opinions demonstrate exactly the same hierarchy of probability. Among Faculty of Tourism Economy (FTE) employees, opinions on impacts 5, 6, 7 were slightly different, though they still did not differ by more than one position in the ranking.

Table 8. Trend 4 - 'information technologies' - impact rankings compilation

\begin{tabular}{|l|c|c|c|}
\cline { 2 - 4 } \multicolumn{1}{c|}{} & FTE employees & Students & TA employees \\
\hline Impact 1 & I & I & I \\
\hline Impact 2 & II & II & II \\
\hline Impact 3 & VI & VI & VI \\
\hline Impact 4 & VII & VII & VII \\
\hline Impact 5 & IV & III & III \\
\hline Impact 6 & IV & V & V \\
\hline Impact 7 & V & IV & IV \\
\hline
\end{tabular}

Source: authors.

As regards opinions about technological trends, the results for trend 9 ('Experiences') were completely different with the opinions in the impact rankings were clearly more diversified. Without going into much detail, let us just note (Table 9) that even if in all groups the respondents above all pointed to impact 1 , the least probable were impact 5 , indicated by students; impact 3 , indicated by the FTE employees; and impact 4, indicated by travel agency employees.

Table 9. Trend 9 - 'experiences' - impact rankings compilation

\begin{tabular}{|l|c|c|c|}
\cline { 2 - 4 } \multicolumn{1}{c|}{} & FTE employees & Students & TA employees \\
\hline Impact 1 & I & I & I \\
\hline Impact 2 & IV & III & IV \\
\hline Impact 3 & VI & IV & III \\
\hline Impact 4 & II & V & VI \\
\hline Impact 5 & IV & VI & V \\
\hline Impact 6 & V & II & II \\
\hline
\end{tabular}

Source: authors.

It appears, then, that the students' intuitive indicators did not differ much from those based on the knowledge and experience of university and travel agency employees who professionally deal with monitoring the situation on the tourism market. 


\section{CONCLUSIONS}

The discussion presented in the article shows characteristic features of students who can participate in research on the identification and forecasting of transformations in tourism. However, before we present the profile of a student as a 'specialist', let us note that the results of the study positively verified the questions at the beginning of the article. The students included in the study critically assessed the world around them, which was expressed by allocating a low probability to some impacts considered by specialists to be significant. Moreover, the students were able to refer to what they had learned during their university study as well as to their observations of surrounding reality, and supplementing the set of impacts they had been presented with by their own indicators and ideas. Although this particular theme was not developed as part of the research results analysis presented here, it is worth adding that student respondents were willing to add their own impacts concerning the trends which they analysed as part of their chosen specialisation (this was particularly clear among students specializing in 'SPA centres management' who gladly expressed their opinions about the 'Health' trend).

Research question 1 ('Does the student have objective knowledge and analytical skills which allows her/ him to reflect on the complex and multifaceted sphere of tourism?') can be answered affirmatively, with two reservations. The results confirmed that students had knowledge which enabled them to approach the extremely complex reality of tourism with understanding, and they were, to a large extent, able to assume attitudes to its various dimensions. It could be detected, however, that there are areas in which they felt more confident and were more willing to express their views (e.g. demography, information technologies) than other fields where the statements were more limited (e.g. those regarding experiences), but this may be regarded as quite natural. Moreover, the analytical skills, mentioned above, can be classified (at least on the basis of the research presented here) as rather soft, connected with the ability to associate and connect certain phenomena or facts. In the course of our research, hard skills, connected with an aptitude to perform tasks related to market analysis, were not verified.

Question 2 ('Is the student capable of taking a critical attitude to the trends, identified by specialists, which define transformations in the sphere of tourism?') can also be answered affirmatively. Students' assessments oscillated between answers 'strongly agree' and 'agree' (which was confirmed in comparative studies among students, university employees and travel agency employees) which can hardly be criticised. We should note, however, that students relatively rarely chose the answer 'undecided', so they turned out to be decisive as regards holding their own position.

The answer to question 3 ('Is the student able to creatively develop the set of trends describing the transformations identified by specialists, supplementing it with accurate indicators based on their own knowledge, personal experience, intuition, etc.?') cannot be confirmed. On the one hand, the picture that emerged from the entire sample seems quite optimistic, as the students extended the set of impacts they had been given with several dozen indicators of their own with reference to each of the trends. On the other hand, however, those additional indicators were from the whole sample. For instance, with reference to trend 5 ('Information technologies'), students added 60 impacts but they were individual indicators. Thus, taking into consideration the number of respondents ( $\mathrm{n}=95)$, it is easy to notice that there were only 0.6 original ideas per student. This result must be regarded as quite modest, considering the fact that we are talking about long-term phenomena and not only in tourism. Leaving aside the respondents' potential unwillingness to make a mental effort by writing an individual, well thought-out, entry in the questionnaire (typical for a survey), it seems that students collectively are creative and their observations may accurately supplement specialists' opinions, but an average (statistical) student does not present a satisfactory level in this respect. As a group, students seem to be valuable participants for a brain storm type of study, but in order to prepare more specific projections, it seems necessary to conduct a selection among the students' collective. Hence, we consider engaging students in preliminary, project, pilot, etc. research to be sensible.

Based on our observations, we may positively, though with caution, verify the research hypothesis proposed in this article ('Tourism students are able to notice trends in tourism which fit in with specialist indicators'). The general picture of students, emerging from the several studies presented here, is on the whole positive. Students collectively turned out to be decisive and creative, making many valuable observations of their surrounding reality and were able to articulate them convincingly. The average picture of a student as an individual is slightly different. It shows a person with considerable knowledge, but not very willing to formulate extended statements regarding the predicted impacts of individual trends. It must be remembered, however, that this last conclusion may be, at least partly, the result of the method that was chosen which might have encouraged only some students to express their opinions. In the light of this, it seems that engaging students in the role of 'specialists' skilfully (organizing team research, an attractive research formula, raising respondents' self-appreciation, etc.) may prove to be a valuable element in research by specialists. 
Finally, it must be emphasised that the trends and impacts assessed by the students were somewhat 'historical', i.e. established by specialists about ten years earlier (in the first decade of the 21st century). The original research method gradually evolved and from the point of view of the aims of this work, it made sense to present the results using an extended questionnaire. It should also be remembered that even if the trends and their impacts have lost their clarity, they have not become outdated in any significant way. This is proved by the long-lasting nature of trends themselves, the relatively generalised way of formulating them, as well as the confrontation with more current sets of trends presented in the literature on the subject. In recent years, many new prognostic reports and works analysing trends on the tourism market have been published (e.g. Amadeus, 2020; CREST, 2019; CTD, 2018; EU, 2017; Expedia, 2017; Future Fundation, 2009; Geerts, 2018; Harwath HTL, 2015; KPMG, Movat, 2013; Mazars, 2018; Nordin, 2005; OECD, 2018, 2020; Scott, Gössling, 2015; UNWTO, 2011; WT\&TC, Bloomberg, 2019). However, their analyses indicate that the forecasts and trends presented earlier were basically correct and, in most cases, we can expect them to continue.

\section{ENDNOTES}

${ }^{1}$ The essence of a megatrend was aptly expressed by $\mathrm{Mu}-$ szyński (2006, p. 89), who wrote that “...the term is defined by phenomena, processes and events referring to the main domains of human life, i.e. economic, social, political, cultural relationships, as well as human awareness, which, in the process of development, acquire the character of stable tendencies, increasingly influencing and penetrating the whole humanity; they were formed in different conditions and depended on different factors and causative mechanisms, as a result of the civilizational development of mankind and, starting from the second half of the $20^{\text {th }}$ century, they have been gaining in importance and penetrating deeper and deeper into the life of societies". This issue has been discussed more broadly by Naisbitt (1982). A microtrend, in turn, signifies phenomena occurring in small communities (often as opposed to the mainstream), while the term "vogue" refers to phenomena of varying range of influence, but shortterm and often generated by business, celebrities, etc. (Hajdas, Izabela-Pasierbińska, 2016).

${ }^{2}$ Many authors quote the classification proposed by Cole (2007), including forecasting, predicting, survey and specialist research.

${ }^{3}$ The review of universities and courses with respect to tourism is included in: Długosz, Biały (2011).

${ }^{4}$ The question of the multidisciplinary character of tourism studies is discussed in: Ozimek, Rutkiewicz (2011).

${ }^{5}$ Let us stress that the multifacetedness of tourism studies is not a new phenomenon - it has always been typical (see, e.g.: Kruczek, 1998).

${ }^{6}$ As it was mentioned earlier, the questionnaire modifications are the reason why the authors of this article did not include the analysis of one of the 11 studied trends - "Economy". The notes regarding the impacts/implications of this trend were changing in subsequent years.

\section{REFERENCES}

Alejziak, B. (2014). Kwalifikacje i kompetencje pracowników turystyki. Próba diagnozy turystycznego rynku pracy. Folia Turistica, 32, 117-144.

Alejziak, W. (2012). Sekwencyjna analiza trendów turystycznych (SATT) jako instrument diagnozowania zmian w popycie turystycznym. Ekonomiczne Problemy Ustug, 82, 27-42.

Alejziak, W., Szczechowicz, B. (2019). Globalizacja a rozwój turystyki - implikacje dla planowania i polityki turystycznej. In: Uwarunkowania i plany rozwoju turystyki. Tom XXII: Planowanie i polityka turystyczna (pp. 9-27). Poznań: Uniwersytet A. Mickiewicza, Bogucki - Wydawnictwo Naukowe.

Amadeus (2020). Future traveller tribes 2020. Retrieved from: http:// www.amadeus.com/travellertribes (25.03.2020).

Bednarska, M. (2013). Kierunek kształcenia a planowana kariera zawodowa - studium empiryczne kierunków związanych $\mathrm{z}$ turystyką. E-mentor, 4 (51). Retrieved from: http://www.e-mentor.edu.pl/artykul/index/numer/51/id/1039 (25.03.2020).

Borodako, K. (2008). Foresight w turystyce. Bariery wykorzystania i rozwoju. Warsaw: Wydawnictwo C.H. Beck.

Buchta, K., Skiert, M., Sikora, J. (2012). Przedsiębiorczość jako element przygotowania zawodowego studentów turystyki i rekreacji. Ekonomiczne Problemy Turystyki, 20, 59-73.

Chomątowska, B., Żarczyńska-Dobiesz, A. (2014). Pokolenie „Z" na rynku pracy - wyzwania dla zarządzania zasobami ludzkimi. Prace Naukowe Uniwersytetu Ekonomicznego we Wrocławiu, 350, 405-415. DOI: https://doi.org/10.15611/pn.2014.350.36

Coathup, D. (1999). Dominant actors in international tourism. International Journal of Contemporary Hospitality Management, 11 (2/3), 69-72. DOI: https://doi.org/10.1108/09596119910250689

Cole, S. (2007). Dare to dream: Bringing futures into planning. Journal of the American Planning Association, 67 (4), 372-383. DOI: https://doi.org/10.1080/01944360108976246

CREST (2019). The case for responsible travel: Trends \& statistics 2019. Retrieved from: https://www.responsibletravel.org/docs/ CaseforResponsibleTravel_2019_Web.pdf (22.03.2020).

CTD (2018). All change? The first report of the commission on travel demand the future of travel demand and the implications for policy and planning. Retrieved from: http://www.demand.ac.uk/ wp-content/uploads/2018/04/FutureTravel_report_final.pdf (20.02.2020).

Długosz, Z., Biały, Sz. (2011). Studia w zakresie turystyki na tle szkolnictwa wyższego w kraju. Przedsiębiorczość - Edukacja, 7, 346-360.

van der Duim, R., Ren, C., Jóhannesson, G.T. (2013). Ordering, materiality, and multiplicity: Enacting Actor-Network Theory in tourism. Tourism Studies, 11, 1-18. DOI: https://doi. org/10.1177/1468797613476397

EC (2009). Mapping foresight. Revealing how Europe and other world regions navigate in to the future. Bruksela: European Commission. Retrieved from: http://www.forschungsnetzwerk.at/downloadpub/2009_efmn_mappingForesight_EU.pdf (21.02.2020).

ETC (2006). Tourism trends for Europe. Retrieved from: http://www. etc-corporate.org/resources/uploads/ETC_Tourism_Trends_ for_Europe_09-2006_ENG.pdf (10.02.2020).

ETC, ETAG (2003). Tourism trends for Europe. Retrieved from: http://www.etc-corporate.org/images/uploads/Diptych\%20 ETC-ETAG.pdf (6.10.2010).

EU (2017). Management and content provision for ICT and tourism business support portal. Retrieved from: https://ec.europa.eu/ growth/content/management-and-content-provision-ict-and-tourism-business-support-portal_en (6.12.2018).

Expedia (2017). Millennial traveller report: Why millennials will shape the next 20 years of travel. Retrieved from: https://travelblog. 
expedia.com.sg/wp-content/uploads/2017/03/Expedia-FutureFoundation-Report-Jan-2017-FINAL.pdf (10.05.2018).

Future Foundation (2009). Travel and tourism in 2020 prepared by the future foundation: The key drivers. Retrieved from: http:// www.foresightfordevelopment.org/sobipro/55/822-travel-and-tourism-in-2020-prepared-by-the-future-foundation-the-key-drivers (17.04.2011).

Gałek, K. (2011). Wpływ megatrendów cywilizacyjnych na rozwój wspótczesnego rynku turystycznego (ze szczególnym uwzględnieniem trendów ekonomicznych i politycznych). Master thesis. Promoter: W. Alejziak. Rzeszów: Wyższa Szkoła Informatyki i Zarządzania w Rzeszowie.

Geerts W. (ed.) (2018). Megatrends shaping the future of travel 2018. London: Euromonitor International.

Głąbiński, Z. (2010). Przygotowanie absolwentów kierunków i specjalności turystycznych do pracy w gospodarce turystycznej a oczekiwania rynku. In: S. Tanaś (ed.), Nauka $i d y$ daktyka w turystyce i rekreacji (pp. 257-262). Łódź: Łódzkie Towarzystwo Naukowe.

Gołembski, G. (2016). Nowe formy kształcenia w obszarze turystyki. Folia Turistica, 41, 63-80. DOI: https://doi. org/10.5604/01.3001.0010.4004

Grabiński, T., Wydymus, S., Zeliaś, A. (1993). Metody prognozowania rozwoju społeczno-gospodarczego. Wyd. II, poprawione i uzupełnione. Cracow: Akademia Ekonomiczna.

Hajdas, M., Szabela-Pasierbińska, E. (2016). Metody przewidywania trendów w makrootoczeniu. Zeszyty Naukowe Uniwersytetu Ekonomicznego we Wrocławiu, 459, 232-244. DOI: https://doi. org/10.15611/pn.2016.459.22

Harwath HTL (2015). Tourism megatrends - 10 things you need to know about the future of tourism. Retrieved from: http://corporate.cms-horwathhtl.com/wp-content/uploads/sites/2/2015/12/ Tourism-Mega-Trends4.pdf (10.06.2016).

Inskeep, E. (1991). Tourism planning - an integrated and sustainable development approach. New York: Van Nostrand Reinhold.

KPMG, Movat (2013). Future State 2030: The global megatrends shaping governments. Toronto: KPMG and Mowat Centre.

Kruczek, Z. (1998). Kształcenie dla potrzeb turystyki w regionie małopolskim. Folia Turistica, 8, 5-16.

Kusiak, M. (2011). Wpływ megatrendów technologicznych i ekologicznych na funkcjonowanie rynku turystycznego. Master thesis. Promoter: W. Alejziak. Warsaw: Wyższa Szkoła Informatyki i Zarządzania w Warszawie.

Łubkowska, W., Nadobnik, J., Tarnowski, M., Nowak, M.A. (2017). Samoocena wiedzy, umiejętności zawodowych i kompetencji społecznych studentów podstawą ewaluacji programu studiów kierunku turystyka i rekreacja. Prace Naukowe Akademii im. Jana Długosza w Częstochowie, XVI (4), 145-161. DOI: https:// doi.org/10.16926/kf.2017.16.43

Mazars (2018). Artificial intelligence: A game changer in the hospitality industry. Retrieved from: https://www.mazars.pl/content/ download/945503/49214764/version//file/Mazars_2018_AI_in_ Hospitality_Study.pdf (10.01.2019).

Muszyński, J., (2006). Społeczeństwo informacyjne. Szkice politologiczne. Toruń: Adam Marszałek.

Naisbitt, J. (1982). Megatrends. Ten new directions transforming our lives. New York: Fortuna Publications.
Nordin, S. (2005). Tourism of tomorrow: Travel trends and forces change. Retrieved from: http://www.turism.se/media/ Undersokningar\%20av\%20varde/Tourism\%20of\%20tomorrow.pdf (20.05.2018).

OECD (2018). Analysing megatrends to better shape the future of tourism. Retrieved from: https://www.oecd-ilibrary.org/industry-and-services/analysing-megatrends-to-better-shape-the-future-of-tourism_d465eb68-en (12.09.2019)

OECD (2020). Tourism trends and policies 2020. Paris: OECD. Retrieved from: https://www.oecd.org/cfe/tourism/oecd-tourism-trends-and-policies-20767773.htm. DOI: https://doi. org/10.1787/6b47b985-en

Ozimek, I., Rutkiewicz, A. (2011). Interdyscyplinarność studiów na kierunku turystyka i rekreacja - przykład Międzywydziałowego Studium Turystki i Rekreacji SGGW w Warszawie. Studia i Materiaty CEPL w Rogowie, 13 (3/28), 28-33.

Pearce, P.L. (2005). The role of relationships in the tourist experience. In: W.F. Theobold (ed.), Global tourism (pp. 103-122). Wydanie 3. Burlington: Elsevier. DOI: https://doi.org/10.1016/ B978-0-7506-7789-9.50012-1

Penc, J. (1997). Strategie zarządzania. Perspektywiczne myślenie, systemowe działanie. Warsaw: Agencja Wydawnicza Placet.

Pichura, M. (2011). Wpływ megatrendów demograficznych $i$ społeczno-kulturowych na rozwój wspótczesnego rynku turystycznego. Master thesis. Promoter: W. Alejziak. Rzeszów: Wyższa Szkoła Informatyki i Zarządzania w Rzeszowie.

Scott, D., Gössling, S. (2015). What could the next 40 years hold for global tourism? Tourism Recreation Research, 40 (3), 269-285. DOI: https://doi.org/10.1080/02508281.2015.1075739

Skiert, M., Buchta, K. (2014). Jakość kształcenia na kierunku turystyka i rekreacja w świetle oczekiwań rynku turystycznego. Prace Naukowe Uniwersytetu Ekonomicznego we Wrocławiu, 353, 145-154. DOI: https://doi.org/10.15611/pn.2014.353.13

Szymańska, E. (2009). Oczekiwania rynku turystycznego w zakresie kształcenia kadr. Economy and Management, 1, 133-140.

Tokarz-Kocik, A. (2016). Kształcenie kadr dla potrzeb obsługi ruchu turystycznego. Zeszyty Naukowe Uniwersytetu Szczecińskiego. Ekonomiczne Problemy Turystyki, 2 (34), 377-385. DOI: https:// doi.org/10.18276/ept.2016.2.34-31

UNWTO(2011). Tourism towards 2030 global overview. Retrieved from: https://www.globalwellnesssummit.com/wp-content/uploads/Industry-Research/Global/2011_UNWTO_Tourism_ Towards_2030.pdf (23.03.2018).

Wodejko, S. (ed.) (2006). Gospodarka turystyczna a grupy interesu (2006). Warsaw: Szkoła Główna Handlowa.

WT\&TC, Bloomberg (2019). World, transformed: Megatrends and their implications for travel \& tourism. London, UK: World Travel \& Tourism Council, Bloomberg Media Group.

Yiannakis, A., Gibson, H. (1992). Roles tourists play. Annals of Tourism Research, 19, 287-303. DOI: https://doi. org/10.1016/0160-7383(92)90082-Z

Article received:

13 April 2020

Accpeted:

17 November 2020 